\title{
Efficacy of homeopathic remedies as prophylaxis of bovine endometritis
}

\author{
S. Arlt, W. Padberg, M. Drillich, and W. Heuwieser ${ }^{1,2}$ \\ Clinic for Animal Reproduction, Faculty of Veterinarian Medicine, Freie Universität Berlin, Königsweg 65, 14163 Berlin, Germany
}

\begin{abstract}
The objective of this study was to evaluate the efficacy of 2 different homeopathic prophylactic strategies for the prevention of endometritis. The drugs used were Lachesis compositum (Lachesis), Carduus compositum (Carduus), and Traumeel LT (Traumeel). Each drug contained a mixed formula of homeopathic remedies. All 929 cows received the first treatment within 24 $\mathrm{h}$ postpartum. The second to fourth treatments were conducted at 7 to 13,14 to 20 , and 21 to $27 \mathrm{~d}$ in milk, respectively. In the first group, the 4 treatments were Traumeel, Lachesis, Carduus, and Carduus, respectively $(\mathrm{n}=206)$. In the second group, Lachesis was administered 3 times, followed by 1 treatment with Carduus $(\mathrm{n}=198)$. The control group received 4 injections of saline $(\mathrm{n}=189)$. In the fourth week after calving, the prevalence of clinical endometritis, uterine involution, and ovarian activity was monitored by rectal palpation and by ultrasonography. To assess the resumption of ovarian activity, blood samples were taken to determine the concentration of serum progesterone. The concentrations of $\beta$-hydroxybutyrate and nonesterified fatty acids in blood serum were examined to evaluate energy metabolism. The incidence of clinical endometritis at 21 to $27 \mathrm{~d}$ in milk did not differ between the groups (44.4, 44.8, and $36.9 \%$ in the Traumeel, Lachesis, Carduus, and Carduus group; the $3 \times$ Lachesis, followed by Carduus group; and the control group, respectively). The proportion of cows with cyclic activity at 21 to $27 \mathrm{~d}$ in milk and the proportion of cows above threshold values of progesterone, $\beta$-hydroxybutyrate, and nonesterified fatty acids did not differ significantly between groups. When reproductive performance data were analyzed, no significant differences were found between groups. Hence, the treatment protocols tested were not effective in preventing bovine endometritis or in enhancing reproductive performance in this study.
\end{abstract}

Received February 18, 2009.

Accepted June 23, 2009.

${ }^{1}$ Corresponding author: wolfgang.heuwieser@ubc.ca

${ }^{2}$ Current address: Animal Welfare Program, Faculty of Land and Food Systems, The University of British Columbia, 2357 Main Mall, Vancouver V6T 1Z4, Canada.
Key words: endometritis, homeopathic prophylaxis, reproductive performance

\section{INTRODUCTION}

Clinical endometritis is a common disease of dairy cows that causes subfertility (Sheldon and Dobson, 2004) and economic losses (Esslemont and Peeler, 1993). It is defined as a superficial inflammation of the endometrium (Sheldon et al., 2006b) and is characterized by the presence of a purulent ( $>50 \%$ pus) uterine discharge detectable in the vagina at $\geq 21$ DIM or by a mucopurulent (approximately 50\% pus and 50\% mucus) discharge detectable in the vagina at $\geq 26$ DIM (Sheldon et al., 2006a).

A wide variety of treatments for endometritis have been reported and discussed controversially among veterinary practitioners (LeBlanc et al., 2002a). These therapies include the local or systemic administration of antibiotics or application of hormones (i.e., $\mathrm{PGF}_{2 \alpha}$; LeBlanc et al., 2002b). Relevant issues for discussion regarding endometritis are the diagnostic criteria, criteria for treatment or nontreatment, efficacy of therapies, and expected reproductive performance (LeBlanc et al., $2002 b$ ). Effective programs for the prevention or reduction of uterine infections have not been implemented successfully on many farms (Sheldon and Dobson, 2004). Thus, the overall incidence of endometritis has not improved significantly over the last 35 yr (Griffin et al., 1974; Sheldon et al., 2002).

In the United States, the health care of organic livestock has to be facilitated by vaccines and other veterinary biological products (USDA, 2002). Only if these interventions are inadequate is administration of synthetic medications, as listed in the National Organic Regulation, allowed. In Europe, the use of veterinary medical products for organic livestock production is regulated by European Council Regulation (EEC) 2092/91 Annex 1, B 5.4 (European Commission, 1991). According to this regulation, the use of phytotherapeutic products, homeopathic products, and trace elements should be preferred to the use of chemically synthesized allopathic veterinary medicinal products or antibiotics, provided they are efficacious for the intended species 
and condition (European Commission, 1991). Hence, the challenge for the practitioner is to assess, for any given case, whether an alternative treatment or a conventional medication should be used. The most critical problem is that little scientific evidence is available concerning the efficacy of phytotherapeutic and homeopathic remedies in farm animals (Arlt, 2006). Without science-based data, however, it is impossible to comply with legal requirements and implement efficacious therapies.

Homotoxicology is a complementary and alternative therapy that uses homeopathically diluted remedies with the intent to eliminate toxins from the body (Ernst and Schmidt, 2004). The expression "alternative therapy" indicates that the intervention does not follow generally accepted medical methods and, recently, that it may not have a scientific explanation for its effectiveness. Recommendations for the treatment of bovine endometritis with homotoxicological drugs often do not refer to valid scientific data but to personal experience (Dorenkamp, 1991). In one of the few field trials on homeopathic treatment of bovine endometritis, Boitor et al. (1994) included 57 cows with puerperal endometritis and treated 27 animals with $10 \mathrm{~mL}$ of Lachesis compositum (comp.) ad usum (us.) veterinarium (vet.) subcutaneously. The control group received an intrauterine treatment with an undefined formulation and dose of oxytetracycline $(\mathrm{n}=30)$. The authors found a significantly improved involution of the uterus, enhanced phagocytosis, and fewer days open (85 vs. 140 d) in study cows compared with control cows. This study, however, had significant deficiencies, such as a small number of animals, a lack of randomization and blinding, and missing definitions for the particular types and times of treatments. Information on the selection and allocation of animals and statistical procedures were also not provided.

In a randomized, controlled, blinded trial, Enbergs and Vorwig (1995) treated 35 cows with Traumeel ad us. vet., Lachesis comp., and Carduus comp. at 1, 7, and 14 DIM, respectively. At the same times, another 37 cows received Lachesis comp., whereas 33 cows treated with saline served as controls. First heat was observed earlier in both treatment groups. Cows that received Traumeel ad us. vet., Lachesis comp., and Carduus comp. were more likely to be cyclic at an undefined point in time compared with control cows.

Enbergs and Sensen (2007) treated 214 cows with $4 \%$ metacresol sulfonic acid formaldehyde polycondensate intrauterinely and 174 cows with the same solution and administered Mucosa comp. intramuscularly, a mixed formula of homeopathic remedies. Cows that received Mucosa comp. had a significantly shorter interval to pregnancy, a lower insemination index (parameter not defined in this article), and a higher first-service pregnancy rate.

In a randomized, double-blinded study by Fidelak et al. (2007), 76 organic dairy cows were treated with Carduus comp. and Coenzyme comp. at the day of drying off, Traumeel on the day of calving, and Lachesis comp. at 14 DIM. Control cows received saline according to the same protocol. Cows in the treatment group showed an earlier onset of cyclic activity but a lower submission rate. Regarding subgroups, the authors concluded that only cows with a higher milk yield showed a positive effect from the treatment. (Average milk yield in this study was $5,100 \mathrm{~kg} /$ cow per lactation.) No other significant differences were found.

The objective of this double-blinded, randomized, and controlled study was to evaluate 2 different homeopathic treatment protocols for the prevention of clinical endometritis in dairy cows. The homeopathic remedies were selected and the treatment protocol was designed by an expert panel of practitioners certified in the field of alternative medicine, advisors experienced in designing and conducting studies on homeopathy in cattle, the manufacturer, and the authors. The basis for the treatment protocols was published specifications on the effect of the remedies (Reinhart and Löw, 2001), the results of the above-cited studies, and the experience of experts.

The drugs used in this study were Lachesis compositum $\mathrm{N}$ ad us. vet. (Lachesis), Carduus compositum ad us. vet. (Carduus), and Traumeel LT ad us. vet. (Traumeel; all from Heel, Baden-Baden, Germany). The drugs contained a mixed formula of homeopathic remedies. The abbreviation "D" behind the remedies represents a decimal dilution ratio of 1:10. The digit describes the frequency of serial dilution. Lachesis consists of Lachesis mutus D6, Pyrogenium nosode D6, Juniperus sabina D3, Echinacea angustifolia D1, and Pulsatilla pratensis D2. According to many authors, Lachesis can be used for several conditions of inflammation (Dorenkamp, 1991; Boitor et al., 1994). Enbergs (2000) reported that Carduus enhances the metabolic condition. This remedy is composed of Silybum marianum D1, Chelidonium majus D3, China (Cinchona pubescens) D2, Colocynthis D5, Lycopodium clavatum D2, Nux Moschata D3, Veratum album D5, and phosphorus D5. Traumeel contains Aconitum napellus D4, Arnica montana D4, Atropa belladonna D4, Bellis perennis D4, Calendula officinalis D4, Chamomilla recutita D5, Echinacea D4, Echinacea purpurea e planta tota D4, Hamamelis virginiana D4, Hypericum perforatum D4, Achillea millefolium D5, Symphytum officinale e radice D8, Hepar sulfuris D6, and Mercurius solubilise D8. According to Enbergs (1998), Traumeel can be used against traumatic insults. 
During parturition, the physical barriers of the cervix, vagina, and vulva are compromised, providing the opportunity for bacteria to ascend the genital tract and cause endometritis and subfertility (Sheldon and Dobson, 2004). In addition, relationships between nutrition and reproductive performance have been well documented (Butler et al., 2006; Lucy, 2001).

The first strategy contained Traumeel, Lachesis, and Carduus. Traumeel was selected for immediate administration after parturition to palliate complications after trauma caused by parturition (Reinhart, 1998). Results of the few published studies indicate a possible positive effect in treatment of acute injuries and trauma (Enbergs, 2000; Schneider et al., 2008) and modulation of the immune response (Porozov et al., 2004). According to Reinhart and Löw (2001) and Boitor et al. (1994), Lachesis stimulates the local immune defense mechanisms and regeneration of the mucosa. Huemmelchen (2002) and Reinhart and Löw (2001) assumed that Carduus was able to prevent nutritional hepatic disorders. Thus, Carduus may help to moderate the effects of the negative energy balance in the first trimester of lactation.

The second strategy focused on a possible antiinflammatory effect of the homeopathic remedies. Hence, cows received 3 administrations of Lachesis in the first $3 \mathrm{wk}$ after calving. In addition, Carduus was administered to moderate the metabolic condition.

\section{MATERIALS AND METHODS}

The study was conducted on a commercial dairy farm in Brandenburg, Germany, from November 2004 to February 2006 with 330 heifers and 720 cows in 2 separate barns. All heifers and cows were kept in groups of 50 to 100 animals in free-stall barns with slotted concrete floors. Herd average milk yield was 8,500 in 2004 and $9,000 \mathrm{~kg}$ in 2006. Cows were fed a mixed ration with additional concentrates from automatic feeders according to their current milk yield. Lactating cows were milked 3 times daily. The voluntary waiting period was $42 \mathrm{~d}$. All cows were artificially inseminated on observed estrus. No timed breeding protocols (e.g., Ovsynch) were used. At the beginning of the study, median days to first service was 69 DIM (interquartile range 57.0 to 91.5) and median days open was $104 \mathrm{~d}$ (interquartile range 73.7 to 139.0 ).

The owner of the farm, participating farm workers, and veterinarians were informed about relevant characteristics of the study and agreed with the study design (informed consent). Within the first $24 \mathrm{~h}$ after parturition, all primiparous and multiparous cows were enrolled in the study. Exclusion criteria were systemic antibiotic or hormonal treatments between 0 and 27
DIM, severe injuries at parturition [i.e., pelvic fractures, perineal lacerations, and vaginal phlegmons (palpable swellings of the vagina)], or caesarean section. Cows that received intrauterine antibiotics for the treatment of metritis or that were treated for hypocalcemia or displaced abomasum and animals with palpable adhesions of the uterus were also excluded from the study.

Cows in group TLC2 received $10 \mathrm{~mL}$ of Traumeel (i.m.) as the first treatment on the day of calving. After 7 to 13 DIM, these animals were treated with $10 \mathrm{~mL}$ of Lachesis (i.m.), and after another 7 and 14 d, respectively, $10 \mathrm{~mL}$ of Carduus was administered (i.m.). Cows in group L3C received $10 \mathrm{~mL}$ of Lachesis (i.m.) at the first 3 treatments and $10 \mathrm{~mL}$ of Carduus (i.m.) at 21 to 27 DIM. Animals in the control group received 4 treatments of $10 \mathrm{~mL}$ of $0.9 \%$ saline on the day of calving and at 7 to 13,14 to 20 , and 21 to 27 DIM.

The study was conducted as a double-blinded trial. The remedies were produced as single-dose vials and were labeled $\mathrm{A} 1$ to $\mathrm{A} 4, \mathrm{~B} 1$ to $\mathrm{B} 4$, and $\mathrm{C} 1$ to $\mathrm{C} 4$ at the manufacturing site of the company. Neither the persons who conducted the treatments, examinations, and statistical analyses nor the members of the farm staff were aware of the association between these characters and the remedies or the placebo, respectively.

Cows were assigned to 1 of 3 groups according to the last digit of the ear tag number. Cows with a last digit of 1,2 , or 3 were enrolled in group A, cows with a last digit of 4,5 , or 6 were enrolled in group B, and cows with a last digit of 7,8 , or 9 were allocated to group C. Cows with a last digit of 0 were enrolled according to the second to last digit. All ear tag numbers had been assigned to calves after birth by the national cow identification system (VIT) at least 2 yr before the trial. The unblinding was conducted after the final statistical analyses had been completed. It revealed that cows in group A had received treatment TLC2 and that cows in group B had received treatment strategy L3C. Cows in group C served as controls and had received saline.

Farm workers had been trained by veterinarians from the Clinic for Animal Reproduction (Berlin, Germany) for administration of the first treatment within $24 \mathrm{~h}$ postpartum with solution $\mathrm{A} 1, \mathrm{~B} 1$, or $\mathrm{C} 1$, respectively. These treatments, information about the date and time of calving, and obstetric interventions were recorded on a case report form. At monthly intervals and again at the end of the study, the case report forms were checked for compliance. Cows with incorrect treatments or incomplete examination records were retrospectively withdrawn from the study.

On the scheduled weekly visits, cows received the second treatment (A2, B2, or $\mathrm{C} 2)$ at 7 to $13 \mathrm{DIM}$, the third treatment (A3, B3, or C3) at 14 to 20 DIM, and the fourth treatment $(\mathrm{A} 4, \mathrm{~B} 4$, or $\mathrm{C} 4)$ at 21 to 27 
DIM, administered by a veterinarian from the Clinic for Animal Reproduction.

All cows were examined by external inspection and by palpation of the genital tract per rectum immediately before the last treatment at 21 to 27 DIM (exam 1 ). All clinical findings were documented on the case report form [i.e., the size and contents of both uterine horns, vulvar discharge, the size of the ovaries, and the presence of follicles or corpora lutea (CL)]. Vaginal discharge or fluctuating contents in the uterus were regarded as signs of clinical endometritis. In addition, all cows were examined by transrectal ultrasonography (Easy Scan, BCF Technology Ltd., Livingston, Scotland; 4.5 - to $8.5-\mathrm{MHz}$ linear array transducer) to measure the maximum diameter of the uterine lumen and to detect abnormal contents. Cows with no clinical signs of endometritis but a diameter of the uterine lumen of $\geq 0.5 \mathrm{~cm}$ or visible echogenic contents were also classified as having endometritis (Lincke et al., 2007).

Endometritis was classified into 3 categories: a clear vaginal discharge with flakes of pus, a diameter of the uterine lumen $\geq 0.5 \mathrm{~cm}$ or visible echogenic contents (E1); a mucopurulent discharge or fluctuating contents in the uterus (E2); or a purulent discharge with or without palpable contents in the uterus and palpable fluctuating contents without vaginal discharge (E3).

The diameter of antral follicles and of the CL was assessed by transrectal B-mode ultrasonography of the ovaries. Cows with follicles or CL with a diameter of $\geq 0.5 \mathrm{~cm}$ were regarded as showing cyclic activity (Ginther et al., 1989; Savio et al., 1990).

Cows with signs of endometritis or acyclicity at exam 1 were reexamined 1 wk later (28 to 35 DIM, exam 2). Endometritic or acyclic cows at exam 2 were submitted to a third examination (35 to 41 DIM, exam 3). Cows with endometritis at exam 3 were treated intramuscularly with $0.15 \mathrm{mg}$ of R-cloprostenol (Preloban, Intervet Deutschland GmbH, Unterschleißheim, Germany) and reexamined 2 wk later. In the case of ongoing endometritis, cows were re-treated with $0.15 \mathrm{mg}$ of Rcloprostenol. This schedule was continued until the cow showed no more signs of endometritis.

Other diseases were treated at the discretion of the local veterinarian. All diagnoses and treatments were recorded. If the exclusion criteria were met, cows were withdrawn from the study retrospectively.

To validate the resumption of ovarian activity and the metabolic condition, blood samples from all cows were taken from the coccygeal vein or artery. Blood was collected with an 18-gauge needle into Venosave plain silicone-coated tubes (Terumo Europe N.V., Leuven, Belgium). The blood samples were stored in a mobile refrigerating box (Dometic Waeco International $\mathrm{GmbH}$, Emsdetten, Germany) at $3^{\circ} \mathrm{C}$ for 2 to $4 \mathrm{~h}$. Samples were centrifuged at 2,500 $\times g$ and serum was transferred into 2 -mL serum tubes (2 aliquots). Tubes were labeled and stored at $-25^{\circ} \mathrm{C}$.

One hundred samples taken from each group at exam 1 and 100 samples taken from the same animals at exam 2 were selected by using a random selection plan generated with Excel (Version 2003; Microsoft, Redmond, WA) and submitted for further analysis. All samples were assayed in duplicate by a commercial laboratory. Progesterone (P4) was measured by an RIA (Access Immunoassay Systems, Beckman Coulter, Fullerton, CA). The presence of a functional CL was defined as a P4 level of $>1 \mathrm{ng} / \mathrm{mL}$ (Staples et al., 1990; Janowski et al., 1998; Mateus et al., 2002). The concentration of BHBA in blood serum was assessed by a cyclic enzymatic assay (Wako Autokit 3-HB, Wako Pure Chemical Industries, Osaka, Japan). Values $>1.0 \mathrm{mmol} / \mathrm{L}$ indicated the presence of subclinical or clinical ketosis (Duffield, 2000). An enzymatic colorimetric method assay (Wako NEFA C, Wako Pure Chemical Industries) was used for the quantitative determination of NEFA in serum. Concentrations of $\geq 0.7 \mathrm{mmol} / \mathrm{L}$ indicated metabolic disorders (Duffield, 2004).

Reproductive performance was characterized by days to first AI, first AI conception rate (number of cows pregnant after the first AI divided by the number of cows inseminated $\times 100$ ), services per conception, days to pregnancy, cumulative pregnancy rate (number of cows documented to be pregnant at 200 DIM divided by the number of cows enrolled $\times 100$ ), days to culling, and the proportion of cows culled. Cows not pregnant by 200 DIM were classified as not pregnant, even if they remained in the herd and conceived later in lactation.

\section{Statistical Analyses}

Data were analyzed with SPSS for Windows (Versions 15.0 and 16.0, SPSS Inc., Munich, Germany). The proportion of cows with endometritis and ultrasonographic findings in the 3 groups were compared by chisquare analysis. For the logistic regression as well as for the survival analyses (Cox regression), the confidence interval was set at $95 \%$. The logistic regression model for the risk of endometritis included treatment $(0=$ control; $1=$ TLC2; $2=$ L3C), dystocia $(0=$ no dystocia; $1=$ dystocia $)$, and parity class $(0=$ multiparous; $1=$ primiparous). For the logistic regression model for the risk of conception after first AI as well as for the survival analyses for the hazards of insemination and pregnancy within 200 DIM, treatment, dystocia, and parity were included as covariates. Adjusted odds ratios, hazard ratios, confidence intervals, and $P$-values are reported. Survival analyses for the hazards of insemination and pregnancy within 200 DIM, respectively, were 
Table 1. Number of animals enrolled in 2 homeopathic treatment groups and a control group, number of animals eligible at 21 and 27 DIM (exam 1), excluded animals, and reasons for exclusion within 21 DIM

\begin{tabular}{|c|c|c|c|c|}
\hline \multirow[b]{2}{*}{ Item } & \multicolumn{3}{|c|}{ Treatment $^{1}$ group } & \multirow[b]{2}{*}{ Total } \\
\hline & TLC2 & L3C & Control & \\
\hline Cows enrolled & 309 & 308 & 312 & 929 \\
\hline Cows at exam 1 & 214 & 203 & 200 & 617 \\
\hline Excluded animals & 95 & 105 & 112 & 312 \\
\hline \multicolumn{5}{|l|}{ Reason for exclusion. ${ }^{2} \%$} \\
\hline Systemic administration of antibiotics & 17.2 & 20.8 & 22.4 & 19.9 \\
\hline Intrauterine administration of antibiotics & 4.9 & 4.2 & 4.2 & 4.4 \\
\hline Systemic administration of hormones & 1.0 & 1.3 & 1.0 & 1.1 \\
\hline Hypocalcemia or ketosis & 4.2 & 5.2 & 5.1 & 4.8 \\
\hline Displaced abomasum & 1.3 & 0.6 & 2.2 & 1.4 \\
\hline Uterine adhesions & 0.3 & 0.6 & 0.0 & 0.3 \\
\hline Calving-related injuries & 1.9 & 1.3 & 1.0 & 1.4 \\
\hline
\end{tabular}

performed by censoring cows not inseminated and not pregnant, respectively. For all statistical analyses, the level of significance was set at $\alpha=0.05$.

\section{RESULTS}

A total of 929 primiparous and multiparous dairy cows were initially enrolled in the study and received the first treatments (Table 1). After removing cows that met the exclusion criteria, a total of 617 cows were eligible for final evaluation. Reasons for exclusion showed no significant differences between groups (Table 1).

An assisted calving was recorded for 26.2, 24.1, and $24.5 \%$ in the TLC2, L3C, and control groups, respectively. The overall prevalence of endometritis was $43.4 \%$ (43.1 and $44.3 \%$ in cows and heifers, respectively) at exam $1(P>0.05$; Table 2). No significant differences were found between groups.
Ultrasonographic examination of both ovaries at exam 1 showed that $85.1 \%$ of the animals had follicles with a diameter of $>5 \mathrm{~mm}$ or at least $1 \mathrm{CL}$ with a diameter of $>5 \mathrm{~mm}$ (Table 3 ). Neither a functional follicle nor a CL was found in $8.8 \%$ of the cows. Ovarian cysts with a diameter of $\geq 25 \mathrm{~mm}$ were found in $4.7 \%$ of the animals. No significant differences were found between treatment groups.

From 100 cows of each group, blood samples were taken for the determination of P4, BHBA, and NEFA at exams 1 and 2. Because of the exclusion of some cows, 97 samples from the TLC2 group, 94 samples from the L3C group, and 100 samples from the control group were analyzed.

The proportions of animals with a $\mathrm{P} 4$ level of $>1$ $\mathrm{ng} / \mathrm{mL}$ at exam 1 were $41.2,38.3$, and $46.0 \%$ in the TLC2, L3C, and control group, respectively. The medians (and interquartile ranges) of $\mathrm{P} 4$ at exam 1 were

Table 2. Prevalence of endometritis from 21 to 27 DIM in 2 homeopathic treatment groups and a control group

\begin{tabular}{lcccr}
\hline & \multicolumn{3}{c}{ Treatment $^{2}$ group } \\
\cline { 2 - 4 } Classification of endometritis, ${ }^{1} \%$ & TLC2, $\mathrm{n}=214$ & L3C, $\mathrm{n}=203$ & Control, $\mathrm{n}=200$ & Total, $\mathrm{n}=617$ \\
\hline Healthy & 55.6 & 55.2 & 63.1 & 56.6 \\
E1 & 37.9 & 37.9 & 36.5 & 37.4 \\
E2 & 3.3 & 3.4 & 2.0 & 2.9 \\
E3 & 3.3 & 3.4 & 2.5 & 3.1 \\
Total & 100.0 & 100.0 & 100.0 & 100.0 \\
\hline
\end{tabular}

${ }^{1} \mathrm{E} 1$ = clear mucous vaginal discharge with flakes of pus, a diameter of the uterine lumen of $\geq 0.5 \mathrm{~cm}$, or visible echogenous contents via ultrasound; E2 = mucopurulent discharge or fluctuating contents in the uterus; E3 = purulent discharge with or without palpable contents in the uterus or palpable fluctuating contents without vaginal discharge.

${ }^{2}$ Treatments: TLC2 $=$ Traumeel on the day of calving, Lachesis at 7 to 13 DIM, Carduus at 14 to 20 and 21 to 27 DIM; L3C = Lachesis on the day of calving, 7 to 13 DIM, and 14 to 20 DIM and Carduus at 21 to 27 DIM; control $=4$ treatments with saline at 0,7 to 13,14 to 20 , and 20 to 27 DIM. 
ARLT ET AL.

Table 3. Findings of the ovaries from 21 to 27 DIM in 2 homeopathic treatment groups and a control group

\begin{tabular}{lcccc}
\hline & \multicolumn{3}{c}{ Treatment $^{1}$ group } \\
\cline { 2 - 4 } Item, \% & TLC2, $\mathrm{n}=214$ & L3C, $\mathrm{n}=203$ & Control, $\mathrm{n}=200$ & Total, $\mathrm{n}=617$ \\
\hline Follicles or corpora lutea $>5 \mathrm{~mm}$ & 83.5 & 85.2 & 90.5 & 86.4 \\
No follicles and no corpus luteum $>5 \mathrm{~mm}$ & 9.8 & 10.8 & 6.0 & 8.9 \\
Ovarian cysts $>25 \mathrm{~mm}$ & 6.7 & 4.0 & 3.5 & 4.7 \\
Total & 100.0 & 100.0 & 100.0 & 100.0 \\
\hline
\end{tabular}

${ }^{1}$ Treatments: TLC2 $=$ Traumeel on the day of calving, Lachesis at 7 to 13 DIM, Carduus at 14 to 20 and 21 to 27 DIM; L3C = Lachesis on the day of calving, 7 to 13 DIM, and 14 to 20 DIM and Carduus at 21 to 27 DIM; control $=4$ treatments with saline at 0,7 to 13,14 to 20 , and 20 to 27 DIM.

1.84 (0.00 to 5.21$), 0.91$ ( 0.00 to 6.33$)$, and $1.87(0.00$ to 6.05$) \mathrm{ng} / \mathrm{mL}$ for the TLC2, L3C, and control group, respectively. The proportions of animals with a BHBA level $<1.0 \mathrm{mmol} / \mathrm{L}$ were $82.5,77.7$, and $78.0 \%$ in the TLC2, L3C, and control group, respectively. Medians (and interquartile ranges) of BHBA at exam 1 were 0.64 (0.51 to 0.87 ), 0.64 (0.52 to 0.89 ), and 0.63 (0.49 to 0.63$) \mathrm{mmol} / \mathrm{L}$ for the TLC2, L3C, and control group, respectively. Nonesterified fatty acid values of $<0.7$ $\mathrm{mmol} / \mathrm{L}$ were found in $40.2,42.5$, and $41.0 \%$ of cows in the TLC2, L3C, and control group, respectively. Medians (and interquartile ranges) of NEFA at exam 1 were 0.63 (0.37 to 0.88 ), 0.78 (0.44 to 1.16 ), and 0.75 (0.34 to 1.12$) \mathrm{mmol} / \mathrm{L}$ for the TLC2, L3C, and control group, respectively. Differences between the groups were not significant for any of the tested parameters.

Descriptive reproductive performance data are given in Table 4. Logistic regression revealed that cows with dystocia and assisted calvings had a significantly higher risk $(\mathrm{OR}=1.88, P<0.05)$ for endometritis at exam 1 (Table 5). The risk for endometritis at exam 1 was not affected by treatment or parity. Results of the logistic regression analyses for the risk of conception after first AI showed a statistically significant effect $(\mathrm{OR}=0.67$, $P=0.04$ ), with primiparous cows being at a lower risk for pregnancy than multiparous cows (Table 5). Treatment and dystocia did not affect the risk of conception after first AI. The Cox regression revealed no effect of treatment or other tested covariates on time to first service or to pregnancy (Table 6).

\section{DISCUSSION}

The demand for alternative therapies has been increasing in the last several years (Arlt, 2006). Many authors recommend homotoxicological remedies for the treatment of livestock because they can be used by persons with less experience in homeopathy (Enbergs, 2000). Homotoxicological remedies contain mixed formulas of drugs in homeopathic (minute) doses and are presumed to be effective against specific conditions or ailments. These might help veterinarians meet the European organic regulations. In contrast to classic homeopathy according to Hahnemann (1982), we did

Table 4. Descriptive reproductive performance data in 2 homeopathic treatment groups and a control group

\begin{tabular}{|c|c|c|c|}
\hline \multirow[b]{2}{*}{ Item } & \multicolumn{3}{|c|}{ Treatment $^{1}$} \\
\hline & $\mathrm{TLC} 2, \mathrm{n}=214$ & $\mathrm{~L} 3 \mathrm{C}, \mathrm{n}=203$ & Control, $\mathrm{n}=200$ \\
\hline Cows inseminated, $\%$ & 92.5 & 91.7 & 93.0 \\
\hline Cumulative pregnancy rate. ${ }^{2} \%$ & 79.9 & 79.9 & 84.6 \\
\hline First AI conception rate, ${ }^{3} \%$ & 40.9 & 39.6 & 42.8 \\
\hline \multicolumn{4}{|l|}{ Days to first $\mathrm{AI}^{4}$} \\
\hline Median & 72.0 & 74.0 & 72.5 \\
\hline Interquartile range & $56.0-90.0$ & $53.0-90.0$ & $52.0-86.0$ \\
\hline Minimum, maximum & $29.0,52.0$ & $22.0,196.0$ & $36.0,158.0$ \\
\hline \multicolumn{4}{|l|}{ Days to pregnancy } \\
\hline Median & 99.0 & 101.0 & 90.0 \\
\hline Interquartile range & $72.0-127.0$ & $74.0-138.0$ & $63.0-129$ \\
\hline Minimum, maximum & $36.0,188.0$ & $39.0,196.0$ & $36.0,199.0$ \\
\hline
\end{tabular}

${ }^{1}$ Treatment: TLC2 $=$ Traumeel on the day of calving, Lachesis at 7 to 13 DIM, Carduus at 14 to 20 and 21 to 27 DIM; L3C = Lachesis on the day of calving, 7 to 13 DIM, and 14 to 20 DIM and Carduus at 21 to 27 DIM; control $=4$ treatments with saline at 0,7 to 13,14 to 20 , and 20 to 27 DIM.

${ }^{2}$ Cumulative pregnancy rate $=$ proportion of cows pregnant within 200 DIM.

${ }^{3}$ For cows artificially inseminated within 200 DIM.

${ }^{4}$ For cows pregnant within 200 DIM. 
Table 5. Results of logistic regression analyses for the risk of endometritis from 21 to 27 DIM and the risk of conception after first AI in 2 homeopathic treatment groups and a control group

\begin{tabular}{|c|c|c|c|c|c|c|c|}
\hline \multirow[b]{2}{*}{ Factor } & \multirow[b]{2}{*}{ df } & \multicolumn{3}{|c|}{ Risk of endometritis, ${ }^{1} \mathrm{n}=547$} & \multicolumn{3}{|c|}{ Conception after first $\mathrm{AI}^{2} \mathrm{n}=573$} \\
\hline & & $\mathrm{OR}^{3}$ & $95 \% \mathrm{CI}^{4}$ & $P$-value & OR & $95 \%$ CI & $P$-value \\
\hline Treatment $^{5}$ & 2 & - & - & 0.7 & - & - & 0.62 \\
\hline Control & & Reference & Reference & Reference & Reference & Reference & Reference \\
\hline TLC2 & 1 & 1.02 & $0.68-1.53$ & 0.94 & 0.85 & $0.57-1.29$ & 0.45 \\
\hline L3C & 1 & 1.17 & $0.78-1.77$ & 0.45 & 0.82 & $0.55-1.25$ & 0.36 \\
\hline Dystocia $^{6}$ & 1 & 1.88 & $1.29-2.73$ & 0.001 & 0.72 & $0.48-1.06$ & 0.10 \\
\hline Parity $^{7}$ & 1 & 1.20 & $0.83-1.74$ & 0.33 & 0.67 & $0.45-0.97$ & 0.04 \\
\hline
\end{tabular}

${ }^{1}$ Endometritis: $0=$ no vaginal discharge from 21 to 27 DIM, a diameter of the uterine lumen $<0.5 \mathrm{~cm}$, and no visible echogenous contents by ultrasound; 1 = mucopurulent or purulent vaginal discharge from 21 to 27 DIM, a diameter of the uterine lumen $\geq 0.5 \mathrm{~cm}$, or visible echogenous contents.

${ }^{2}$ Number of cows that conceived after the first AI. Only animals pregnant by 200 DIM were included in the calculation.

${ }^{3} \mathrm{OR}=$ odds ratio.

${ }^{4} \mathrm{CI}=$ confidence interval

${ }^{5}$ Treatment: TLC2 $=$ Traumeel on the day of calving, Lachesis at 7 to 13 DIM, Carduus at 14 to 20 and 21 to 27 DIM; L3C = Lachesis on the day of calving, 7 to 13 DIM, and 14 to 20 DIM and Carduus at 21 to 27 DIM; control $=4$ treatments with saline at 0,7 to 13,14 to 20 , and 20 to 27 DIM.

${ }^{6}$ Dystocia: $0=$ no dystocia, $1=$ dystocia, calvings were assisted by the owners or by a veterinarian.

${ }^{7}$ Parity: 0 = multiparous; 1 = primiparous.

not use an individualized therapy. For individualized therapy, the symptoms of each animal are observed and the remedy that most closely matches the symptoms of the patient is chosen for the treatment. The aim of the study was to use a treatment and examination protocol that could be easily integrated into routine work with weekly farm visits following the established concepts for herd health (Bonnett et al., 1993; LeBlanc et al., 2002b; Kasimanickam et al., 2004).

The prevalence of endometritis was $43.4 \%$ at the time of exam 1. This prevalence is similar to (Falkenberg and Heuwieser, 2005) or higher than (Drillich et al., 2001) the results of other studies performed in large German dairy herds. This can be explained by the more sensitive diagnosis by ultrasound (Fissore et al., 1986; Kasimanickam et al., 2004; Sheldon et al., 2006a). With regard to the prevalence or severity of endometritis, differences were not significant between groups. Thus, the treatment protocols tested were not effective in preventing bovine endometritis in our study. Unfortunately, no science-based information is available in the literature with which to compare our findings.

The proportion of cows without functional follicles or CL was $8.9 \%$ at exam 1 (Table 3 ). The homeopathic treatments did not have any significant effects on the proportion of noncycling cows between groups. However, the percentage of noncycling cows in all groups was lower than reported in several other studies (Opsomer

Table 6. Results of the Cox regression of days to first service and days to conception in 2 homeopathic treatment groups and a control group

\begin{tabular}{|c|c|c|c|c|c|c|c|}
\hline \multirow[b]{2}{*}{ Factor } & \multirow[b]{2}{*}{ df } & \multicolumn{3}{|c|}{ Days to first service, $\mathrm{n}=547$} & \multicolumn{3}{|c|}{ Days to conception, $\mathrm{n}=453$} \\
\hline & & $\mathrm{HR}^{1}$ & $95 \% \mathrm{CI}^{2}$ & $P$-value & $\mathrm{HR}$ & $95 \% \mathrm{CI}$ & $P$-value \\
\hline Treatment $^{3}$ & 2 & - & - & 0.48 & - & - & 0.44 \\
\hline Control & & Reference & Reference & Reference & Reference & Reference & Reference \\
\hline TLC2 & 1 & 0.92 & $0.75-1.13$ & 0.41 & 0.86 & $0.69-1.08$ & 0.20 \\
\hline L3C & 1 & 0.88 & $0.72-1.09$ & 0.24 & 0.95 & $0.76-1.18$ & 0.62 \\
\hline Dystocia $^{4}$ & 1 & 0.96 & $0.79-1.17$ & 0.67 & 0.90 & $0.72-1.11$ & 0.32 \\
\hline Parity $^{5}$ & 1 & 1.01 & $0.83-1.21$ & 0.95 & 0.84 & $0.68-1.04$ & 0.11 \\
\hline
\end{tabular}

${ }^{1} \mathrm{HR}=$ hazard ratio.

${ }^{2} \mathrm{CI}=$ confidence interval.

${ }^{3}$ Treatment: TLC2 $=$ Traumeel on the day of calving, Lachesis at 7 to 13 DIM, Carduus at 14 to 20 and 21 to 27 DIM; L3C = Lachesis on the day of calving, 7 to 13 DIM, and 14 to 20 DIM and Carduus at 21 to 27 DIM; control $=4$ treatments with saline at 0,7 to 13,14 to 20 , and 20 to 27 DIM.

${ }^{4}$ Dystocia: 0 = no dystocia; 1 = dystocia, calvings were assisted by the owners or by a veterinarian.

${ }^{5}$ Parity: $0=$ multiparous; 1 = primiparous. 
et al., 2000). Enbergs and Vorwig (1995) observed a significant reduction of noncycling animals in a randomized, controlled, and blinded trial with 105 animals when using homeopathic remedies compared with a control group. These results could not be confirmed by our study. To our knowledge, no other evidence-based information is available for comparison.

The evaluation of $\mathrm{P} 4$ concentrations at exam 1 did not show significant differences between the treatment groups and the control group. Enbergs and Vorwig (1995) measured the concentration of P4 in the milk fat and reported lower days to first estrus for both homeopathic treatment groups (54.8 and $59.1 \mathrm{~d}$ ) compared with control cows $(65.4 \mathrm{~d})$.

When the proportions of cows with a BHBA value of $>1.0 \mathrm{mmol} / \mathrm{L}$ were compared, indicating subclinical or clinical ketosis, no statistically significant differences were found between groups. Thus, we could not confirm that BHBA concentrations were lower in treated animals, as reported earlier (Schlecht et al. (2005).

Furthermore, none of the reproductive performance parameters showed a significant difference between groups. Mean days to first AI varied from 72.0 to 74.0 and pregnancy rate ranged from 79.9 to $84.6 \%$. In the present study, it took 99 to $101 \mathrm{~d}$ to pregnancy, indicating an average herd reproductive performance typical for a German dairy herd. Enbergs and Vorwig (1995) found fewer days to pregnancy in animals treated with homeopathic remedies compared with control animals. In earlier studies, treated animals had significantly fewer days to pregnancy (Enbergs and Sensen, 2007) and fewer services per conception (Boitor et al., 1994). These findings were not confirmed by our study. The first AI conception rate in our study ranged from 39.6 (L3C group) to $42.8 \%$ (control group). These values are comparable with data from similar studies of large German dairy herds (Tenhagen and Heuwieser, 1999; Drillich et al., 2002).

We could confirm that cows with dystocia and subsequent calving assistance had a significantly higher risk for endometritis at exam 1. It also remains unclear why primiparous cows had a lower risk of pregnancy than multiparous cows. This is in contrast to the results from other studies (Drillich et al., 2002; LeBlanc et al., 2002b).

In conclusion, the homeopathic treatment protocols evaluated were not effective in preventing bovine endometritis, improving the metabolic condition, or improving reproductive performance. Because of a negative tendency of some data concerning the treatment groups, a detrimental effect of the homeopathic strategies should be examined in further studies. This study is the only randomized, controlled, and double-blinded clinical trial to be conducted with a sufficient number of animals in the field of homeopathy in cattle. We could not confirm the results of other studies indicating a positive effect of the chosen homeopathic treatment protocols.

\section{ACKNOWLEDGMENTS}

The authors gratefully acknowledge support and funding for the study by Heel (Baden-Baden, Germany) and the cooperation, time, and interest of the farm staff. Particular thanks are due to Erich Reinhart (Heel, Baden-Baden, Germany) for excellent advice and assistance with data management. We also gratefully acknowledge the participants of the expert panel who developed the 2 homeopathic strategies tested in the presented study and B.-A. Tenhagen for statistical advice.

\section{REFERENCES}

Arlt, S. 2006. Naturheilverfahren auf dem Prüfstand. Tierärztl. Umsch. 61:332-333.

Boitor, I., M. L. Bogdan, C. Ghitulescu, and I. Bogdan. 1994. Einsatz der Homoeopathika Lachesis compositum ad us. vet. bei puerperalen Uterusinfektionen und Ovarium compositum ad us. vet. bei Ovarialzysten beim Rind. Biol. Tiermed. 11:44-49.

Bonnett, B. N., S. Wayne Martin, and A. H. Meek. 1993. Associations of clinical findings, bacteriological and histological results of endometrial biopsy with reproductive performance of postpartum dairy cows. Prev. Vet. Med. 15:205-220.

Butler, S. T., S. H. Pelton, and W. R. Butler. 2006. Energy balance, metabolic status, and the first postpartum ovarian follicle wave in cows administered propylene glycol. J. Dairy Sci. 89:2938-2951.

Dorenkamp, B. 1991. Lachesis compositum ad us. vet. zur Behandlung von Puerperalerkrankungen. Biol. Tiermed. 8:36-41.

Drillich, M., O. Beetz, A. Pfützner, M. Sabin, H. J. Sabin, P. Kutzer, H. Nattermann, and W. Heuwieser. 2001. Evaluation of a systemic antibiotic treatment of toxic puerperal metritis in dairy cows. J. Dairy Sci. 84:2010-2017.

Drillich, M., J. Bergmann, U. Falkenberg, A. Kurth, and W. Heuwieser. 2002. Effects of the intensity of a post partum examination on the fertility performance of high yielding dairy cows. Dtsch. Tierarztl. Wochenschr. 109:386-390.

Duffield, T. F. 2000. Subclinical ketosis in lactating dairy cattle. Vet. Clin. North Am. Food Anim. Pract. 16:231-253.

Duffield, T. F. 2004. Monitoring strategies for metabolic disease in transition dairy cows. 23rd World Buiatrics Congr., Quebec City, Canada. Ordre des médecins veterinaries du Québec, Canada.

Enbergs, H. 1998. Wirkung ausgewaehlter potenzierter SuisOrganpraeparate und von Traumeel auf die Aktivitaet von Phagozyten und Lymphozyten aus dem peripheren Blut von gesunden menschlichen Probanden. Biol. Tiermed. 27:3-11.

Enbergs, H. 2000. Praeventiver Einsatz von Homoeopathika zur Reduzierung von Fertilitaetsstoerungen bei Hochleistungsmilchkuehen p.p. Ganzheitl. Tiermedizin 14:14-16.

Enbergs, H., and B. Sensen. 2007. Zur Effizienz homoeopathischer Behandlungen chronischer Endometritiden von Milchkuehen. Prakt. Tierarzt 88:534-543.

Enbergs, H., and W. Vorwig. 1995. Untersuchungen zur Praevention von postpartalen Zyklus- und Fruchtbarkeitsstoerungen bei Hochleistungskuehen durch die homoeopathischen Präparate Traumeel, Lachesis compositum und Carduus compositum. Biol. Tiermed. 95:5-20.

Ernst, E., and K. Schmidt. 2004. Homotoxicology-A review of randomised clinical trials. Eur. J. Clin. Pharmacol. 60:299-306. 
Esslemont, R. J., and E. J. Peeler. 1993. The scope for raising margins in dairy herds by improving fertility and health. Br. Vet. J. 149:537-547.

European Commission. 1991. Council Regulation (EEC) No. 2092/91. http://eur-lex.europa.eu/LexUriServ/LexUriServ.do?uri=CONSL EG:1991R2092:20070101:EN:PDF Accessed Jan. 15, 2009.

Falkenberg, U., and W. Heuwieser. 2005. Influence of time of initiation of a prostaglandin $\mathrm{F}_{2 \alpha}$ protocol in dairy cows with puerperal endometritis. Dtsch. Tierarztl. Wochenschr. 112:252-256.

Fidelak, C., P. Klocke, and W. Heuwieser. 2007. Homoeopathic prophylaxis in dairy cows on an organic farm. Part 1-Fertility. Dtsch. Tierarztl. Wochenschr. 114:258-274.

Fissore, R. A., A. J. Edmonson, R. L. Pashen, and R. H. Bondurant 1986. The use of ultrasonography for the study of the bovine reproductive tract: II. Non-pregnant, pregnant and pathological conditions of the uterus. Anim. Reprod. Sci. 12:167-177.

Ginther, O. J., L. Knopf, and J. P. Kastelic. 1989. Temporal associations among ovarian events in cattle during oestrus cycles with two and three follicular waves. J. Reprod. Fertil. 87:223-230.

Griffin, J. F. T., P. J. Hartigan, and W. R. Nunn. 1974. Nonspecific uterine infection and bovine fertility. I. Infection patterns and endometritis during the first seven weeks postpartum. Theriogenology 1:91-106.

Hahnemann, S. 1982. Organon of medicine-A new translation. J. P. Tarcher, Los Angeles, CA.

Huemmelchen, M. 2002. Stoffwechselstoerungen und peripartale Erkrankungen beim Milchrind-Pro- und Metaphylaxe mit homoeopathischen Arzneimitteln. Biol. Tiermed. 19:64-87.

Janowski, T., S. Zdunczyk, A. Chmielewski, and E. Mwaanga. 1998. Untersuchungen ueber Progesteronprofile bei Kuehen mit puerperalen Endometritiden. Tierärztl. Umsch. 53:399-402.

Kasimanickam, R., T. F. Duffield, R. A. Foster, C. J. Gartley, K. E. Leslie, J. S. Walton, and W. H. Johnson. 2004. Endometrial cytology and ultrasonography for the detection of subclinical endometritis in postpartum dairy cows. Theriogenology 62:9-23.

LeBlanc, S. J., T. F. Duffield, K. E. Leslie, K. G. Bateman, G. P. Keefe, J. S. Walton, and W. H. Johnson. 2002a. Defining and diagnosing postpartum clinical endometritis and its impact on reproductive performance in dairy cows. J. Dairy Sci. 85:2223-2236.

LeBlanc, S. J., T. F. Duffield, K. E. Leslie, K. G. Bateman, G. P Keefe, J. S. Walton, and W. H. Johnson. 2002b. The effect of treatment of clinical endometritis on reproductive performance in dairy cows. J. Dairy Sci. 85:2237-2249.

Lincke, A., M. Drillich, and W. Heuwieser. 2007. Subclinical endometritis in dairy cattle and its effect on reproductive performance- A review on recent publications. Berl. Munch. Tierärztl. Woschr. 120:245-250.

Lucy, M. C. 2001. ADSA Foundation Scholar Award: Reproductive loss in high-producing dairy cattle: Where will it end? J. Dairy Sci. 84:1277-1293.

Mateus, L., L. Lopes da Costa, F. Bernardo, and J. Robalo Silva. 2002. Influence of puerperal uterine infection on uterine involution and postpartum ovarian activity in dairy cows. Reprod. Domest. Anim. 37:31-35.

Opsomer, G., Y. T. Grohn, J. Hertl, M. Coryn, H. Deluyker, and A. de Kruif. 2000. Risk factors for post partum ovarian dysfunction in high producing dairy cows in Belgium: A field study. Theriogenology 53:841-857.

Porozov, S., L. Cahalon, M. Weiser, I. D. Bransk, O. Lider, and M. Oberbaum. 2004. Inhibition of IL-1 $\beta$ and TNF- $\alpha$ secretion from resting and activated human immunocytes by the homeopathic medication Traumeel S. Clin. Dev. Immunol. 11:143-149.

Reinhart, E. 1998. Behandlung von Groß- und Kleintieren mit Traumeel-Eine Übersicht. Biol. Tiermed. 1:4-30.

Reinhart, E., and G. Löw. 2001. Kommentiertes Symptomenverzeichnis der Biologischen Tiermedizin. Aurelia-Verlag, Baden-Baden, Germany.

Savio, J. D., M. P. Boland, N. Hynes, and J. F. Roche. 1990. Resumption of follicular activity in the early post-partum period of dairy cows. J. Reprod. Fertil. 88:569-579.

Schlecht, S., R. Martin, J. Riedl, and R. Mansfeld. 2005. Auswirkungen einer prophylaktischen Verabreichung der Präparate Carduus compositum, Coenzyme compositum, Lachesis compositum und Traumeel LT auf die Eutergesundheit von Milchkühen. Prakt. Tierarzt 86:748-757.

Schneider, C., B. Schneider, J. Hanisch, and R. van Haselen. 2008. The role of a homoeopathic preparation compared with conventional therapy in the treatment of injuries: An observational cohort study. Complement. Ther. Med. 16:22-27.

Sheldon, I. M., and H. Dobson. 2004. Postpartum uterine health in cattle. Anim. Reprod. Sci. 82-83:295-306.

Sheldon, I. M., G. S. Lewis, S. LeBlanc, and R. O. Gilbert. 2006a. Defining postpartum uterine disease in cattle. Theriogenology 65:1516-1530.

Sheldon, I. M., D. E. Noakes, A. N. Rycroft, D. U. Pfeiffer, and H. Dobson. 2002. Influence of uterine bacterial contamination after parturition on ovarian dominant follicle selection and follicle growth and function in cattle. Reproduction 123:837-845.

Sheldon, I. M., D. C. Wathes, and H. Dobson. 2006b. The management of bovine reproduction in elite herds. Vet. J. 171:70-78.

Staples, C. R., W. W. Thatcher, and J. H. Clark. 1990. Relationship between ovarian activity and energy status during the early postpartum period of high producing dairy cows. J. Dairy Sci. 73:938-947.

Tenhagen, B. A., and W. Heuwieser. 1999. Comparison of a conventional reproductive management programme based on rectal palpation and uterine treatment of endometritis with a strategic prostaglandin F2 alpha programme. Zentralbl. Veterinarmed. A 46:167-176.

USDA. 2002. National Organic Program: Production and Handling. http://www.ams.usda.gov/AMSv1.0/getfile?dDocName=STELD EV3003494\&acct=noprulemaking Accessed Jan. 15, 2009. 